\title{
The effect of Liv-52 on liver ischemia reperfusion damage in rats
}

\author{
Orhan Cimen ${ }^{1}$, Hüseyin Eken ${ }^{1}$, Ferda Keskin Cimen², Arif Burak Cekic ${ }^{3}$, Nezahat Kurt ${ }^{4}$, Asli Ozbek Bilgin ${ }^{5}$, \\ Bahadir Suleyman ${ }^{5}$, Halis Suleyman ${ }^{5}$, Renad Mammadov ${ }^{5^{*}}$ (D, Kamil Pehlivanoglu ${ }^{1}$ and Eray Kurnaz ${ }^{1}$
}

\begin{abstract}
Background: Liver ischemia reperfusion (I/R) damage which is frequently seen in clinical hepatobiliary surgeries has no effective treatment for it. Liv-52, known to have hepatoprotective effects, is a natural antioxidant drug licensed by the Ministry of Health of India. The aim of our study is to investigate the effect of Liv-52 on liver damage induced by $\mathrm{I} / \mathrm{R}$ in rats.

Methods: Albino Wistar male rats were divided into three groups; liver I/R (IR), 20 mg/kg Liv-52 + liver ischemia reperfusion (LIR) and sham operation applied to control group (HG). Liv-52 was administered to the LIR group ( $n=$ 6) $1 \mathrm{~h}$ prior to I/R application and distilled water was given orally to IR $(n=6)$ and $\mathrm{HG}(n=6)$ groups as a solvent. Ischemia was determined as $1 \mathrm{~h}$, and reperfusion was identified as $6 \mathrm{~h}$ in animals.

Results: Increased levels of alanine aminotransferase, aspartate aminotransferase and lactate dehydrogenase, malondialdehyde, myeloperoxidase, and decreased levels of superoxide dismutase, and glutathione related enzymes caused by I/R application have been converged to healthy group level with Liv-52 treatment and the damage in liver tissue has been improved histopathologically.
\end{abstract}

Conclusions: Liv-52 may be beneficial for preventing liver I/R damage in pre-surgery application.

Keywords: Ischemia reperfusion, Injury, Liver, Liv-52, Rat

\section{Background}

Hepatic portal occlusion operation or Pringle maneuver interrupting portal vein and hepatic artery entries are temporarily performed to control bleeding control during operations such as liver resection, transplantation and hepatobiliary surgery [1]. This method is widely used since it is clinically simple, practical and effective. However, this methodology can lead to a significant risk of liver damage due to ischemia reperfusion (I/R) [2]. The formation of excessive free radicals is responsible for the reperfusion damage and for the molecular oxygen presented in great amounts with arterial blood to the ischemic tissue [3]. Free oxygen radicals cause cell membrane lipids to oxidize and allow toxic products such as malondialdehyde (MDA) from lipids [4]. The in-

\footnotetext{
* Correspondence: renad_mamedov@hotmail.com

${ }^{5}$ Department of Pharmacology, Faculty of Medicine, Erzincan Binali Yildirim

University, 24100 Erzincan, Turkey

Full list of author information is available at the end of the article
}

formation obtained from the literature suggests that $I / R$ damage is a pathological process that begins with the asphyxiation of the tissues and continues with the production of free oxygen radicals [5]. Therefore, a current shared hypothesis suggests antioxidant drugs may be useful for preventing I/R damage. In this study, we will examine the effects of Liv-52 against I/R liver damage which is licensed as an ayurvedic medicine by the AYUSH department, a drug regulatory authority of the Indian Ministry of Health. Each tablet of Liv-52 contains medicinal plants extracts at specified doses: $65 \mathrm{mg}$ of Capparis spinosa, $65 \mathrm{mg}$ of Cichorium intybus, $33 \mathrm{mg}$ of Mandur Bhasma, $32 \mathrm{mg}$ of Solanum nigrum, $32 \mathrm{mg}$ of Terminalia Arjuna, $16 \mathrm{mg}$ of Cassia occidentalis, $16 \mathrm{mg}$ of Achillea millefolium and $16 \mathrm{mg}$ of Tamarix gallica [6]. It has been reported that Liv-52 protects liver against toxicity of ethanol by preventing the increase of lipid peroxidation and the reduction of antioxidants in rat liver tissue [7].

(c) The Author(s). 2020 Open Access This article is distributed under the terms of the Creative Commons Attribution 4.0 International License (http://creativecommons.org/licenses/by/4.0/), which permits unrestricted use, distribution, and reproduction in any medium, provided you give appropriate credit to the original author(s) and the source, provide a link to the Creative Commons license, and indicate if changes were made. The Creative Commons Public Domain Dedication waiver (http://creativecommons.org/publicdomain/zero/1.0/) applies to the data made available in this article, unless otherwise stated. 
The information obtained suggests that Liv-52 may be useful during $\mathrm{I} / \mathrm{R}$ treatment or may protect the liver tissue from I/R damage. There was no information on the protective effect of Liv-52 against liver I/R damage in literature review. For this reason, the aim of our study is to examine the effect of Liv-52 on the liver damage induced by $I / R$ in rats biochemically and histopathologically.

\section{Methodology}

\section{Animals}

The experimental animals have been received from Atatürk University Medical Experimental Application and Research Center. There were totally 18 experimental animals used in this study and they were all male albino Wistar rats. Their weights varied between 250 and $270 \mathrm{~g}$ (8-10 months). The rats have been kept until the surgery in groups under proper temperature and conditions. The temperature was adjusted as room temperature $\left(22^{\circ} \mathrm{C} \pm 1{ }^{\circ} \mathrm{C}\right)$. They were maintained in a $12: 12$-h lightdark cycle. The study has been carried out according to the National Guidelines for the Use and Care of Laboratory Animals. Moreover the study received the approval from the local animal ethics committee in Ataturk University, Erzurum, Turkey (Ethics Committee Number: 77040475-000-E.1700216877, Dated:03.08.2017).

\section{Chemicals}

Of the chemical substances used for the experiments, thiopental sodium was received from IE.

Ulagay, Istanbul, Turkey. Liv-52 was received from Himalaya Drug, Shankar Nagar, Nagpur, Maharashtra, India.

\section{Experimental groups}

Experimental animals have been categorized in three different groups, with 6 rats in each group and treated as follows: liver ischemia/reperfusion (IR), $20 \mathrm{mg} / \mathrm{kg}$ Liv$52+$ liver ischemia reperfusion (LIR) and sham operation applied to the healthy group (HG).

\section{Experimental procedure}

The surgical interventions on rats were carried out under sterile conditions. Anesthesia was performed by administering $25 \mathrm{mg} / \mathrm{kg}$ of intraperitoneal (ip) thiopental sodium and xylazine by inhalation at appropriate intervals. One hour before thiopental sodium anesthesia, Liv-52 was given to the LIR animal group orally by a catheter at a dose of 20 $\mathrm{mg} / \mathrm{kg}$ and volume of $1 \mathrm{cc}$ as given in previous studies [8]. Also, $100 \mathrm{mg} / \mathrm{kg}$ Liv-52 studied for isoniazid and rifampicin induced hepatotoxicity [9]. $20 \mathrm{mg}$ for $1000 \mathrm{mg}$ rat, each rat weighs between 250 and $270 \mathrm{mg}$. One tablet weighing 320 $\mathrm{mg}$ dissolved in $64 \mathrm{cc}$ distilled water and $1 \mathrm{cc}$ given by gavage orally. $1 \mathrm{cc}$ has $5 \mathrm{mg}$ Liv52(20 mg/ $\mathrm{kg})$ and also contains as one tablet (weighing $320 \mathrm{mg}$ ) of Liv52 contains; Capparis spinosa \%20,3125, Cichorium intybus \%20,3125, Mandur Bhasma \%10,3125, Solanum nigrum \%10, Terminalia Arjuna \%10, Cassia occidentalis \%5, Achillea millefolium $\% 5$ and Tamarix gallica \% 5. Distilled water as solvent was administered to the IR and HG rat groups with the same method. After the injection of thiopental sodium, the rats were kept for the appropriate surgery period. Surgical intervention was applied after the period when the animals were motionless in supine position was considered to be appropriate. During this process, all the rats were brought to supine position and laparotomy was performed by the 3,5-4 $\mathrm{cm}$ long vertical dissection of the abdomen's anterior portion. Later, one hour for ischemia was performed by placing clamps on the hepatic artery, portal vein and bile duct in order to create total hepatic ischemia (excluding the HG group). And after ischemia period $6 \mathrm{~h}$ of reperfusion was provided. At the end of reperfusion period, one blood sample for each rat (each sample replicated three times for biochemical analyzes and averaged) was taken from the tail veins of the animals for the measurement of Alanine aminotransferase (ALT), Aspartate aminotransferase (AST) and Lactate dehydrogenase (LDH) activities. Later, rat groups were killed with high dosage of anesthesia $(50 \mathrm{mg} /$ kg i.p. thiopental sodium IE Ulagay-Türkiye) and their liver tissues were removed. Oxidant/antioxidant parameters were determined from the removed tissues and the tissues were examined histopathologically.

\section{Biochemical measurements \\ Serum alanine aminotransferase, aspartate aminotransferase and lactate dehydrogenase measurements}

Venous blood samples collected into tubes without anticoagulant. Serum was separated by centrifugation after clotting and stored at $-80^{\circ} \mathrm{C}$ until assay. Serum AST and ALT activities as liver function tests, and LDH activity as a marker of tissue injury, were measured spectrophotometrically on a Cobas 8000 (Roche) autoanalyser using commercially available kits (Roche Diagnostics, GmBH, Mannheim, Germany).

\section{Sample preparation for analyses of biochemical parameters} $20 \mathrm{mg}$ of liver tissue weighed for each liver and the samples homogenized in ice with 2-mL buffers (consisting of $0.5 \%$ hexadecyltrimethylammonium bromide) $\mathrm{pH} 6$ potassium phosphate buffer for myeloperoxidase analyze, consisting of $1.15 \%$ potassium chloride solution for thiobarbituric acid reactions (TBARS) analysis and $\mathrm{pH} 7.5$ phosphate buffer for the superoxide dismutase, total glutathione analysis. Then, they centrifuged at $4{ }^{\circ} \mathrm{C}$, $10.000 \times \mathrm{g}$ for $15 \mathrm{~min}$. The supernatant part used as the analysis sample. And each sample replicated three times for biochemical analyzes and averaged. The protein 
concentration of the supernatant measured with the method described by Bradford [10].

\section{Malondialdehyde analysis}

The method of Ohkawa $\mathrm{H}$ et al. used for MDA measurement [11]. This method was based on the spectrophotometric measurement (at a wavelength of $532 \mathrm{~nm}$ ) of the absorbance of the pink colored complex created by thiobarbituric acid (TBA) and MDA at a high temperature $\left(95^{\circ} \mathrm{C}\right)$. The corpus mucosa was scraped, weighed, and homogenized in $10 \mathrm{ml}$ of $100 \mathrm{~g} / \mathrm{L} \mathrm{KCl}$. The homogenate $(0.5 \mathrm{ml})$ was added to a solution containing $0.2 \mathrm{ml}$ of 80 g/l sodium lauryl sulfate, $1.5 \mathrm{ml}$ of $200 \mathrm{~g} / \mathrm{l}$ acetic acid, $1.5 \mathrm{ml}$ of $8 \mathrm{~g} / \mathrm{L} \mathrm{2-thiobarbiturate,} \mathrm{and} 0.3 \mathrm{ml}$ distilled water. The mixture incubated at $98^{\circ} \mathrm{C}$ for $1 \mathrm{~h}$. Upon cooling, $5 \mathrm{ml}$ of $\mathrm{n}$-butanol:pyridine (15:l) added. The mixture vortexed for $1 \mathrm{~min}$ and centrifuged for $30 \mathrm{~min}$ at $1800 \times \mathrm{g}$. The absorbance of the supernatant measured at $532 \mathrm{~nm}$. The standard curve obtained using 1,1,3,3tetramethoxypropane (1.56-3.12 - 6.25 - 12.5 - 25 - 50 $100 \mu \mathrm{M})$.

\section{Myeloperoxidase analysis}

The activity of myeloperoxidase (MPO) in the total homogenate was measured according to the method of Wei and Frenkel with some modifications [12]. The sample was weighed and homogenized in $2 \mathrm{ml}$ of 50 $\mathrm{mmol} / \mathrm{L}$ phosphate buffer containing $0.5 \%$ hexadecyltrimethyl ammonium bromide (HDTMAB) and centrifuged at $1200 \times \mathrm{g}$ for $60 \mathrm{~min}$ at $4{ }^{\circ} \mathrm{C}$. The supernatant was used to determine MPO activity using $1.3 \mathrm{~mL} 4$ aminoantipyrine-2\% phenol $(25 \mathrm{mM})$ solution. $25 \mathrm{mmol} /$ L 4-aminoantipyrine-2\% phenol solution and $1.5 \mathrm{~mL}$ of $0.0005 \% \mathrm{H}_{2} \mathrm{O}_{2}$ were added and equilibrated for 3-4 min. After establishing the basal rate, a $0.2 \mathrm{~mL}$ sample suspension was added and quickly mixed. Increases in absorbance at $510 \mathrm{~nm}$ for $4 \mathrm{~min}$ at 0.1 -min intervals were recorded. Absorbance was measured at $412 \mathrm{~nm}$ using a spectrophotometer.

\section{Superoxide dismutase analysis}

The method of Sun et al. used for the measurement of superoxide dismutase [13]. Xanthine is converted into uric acid using xanthine oxidase. When nitro blue tetrazolium (NBT) was mixed into the reaction, SOD reacted with NBT. The color of the formazan dye became purple. The weight measurement was carried out and the mixture was homogenized in $2 \mathrm{ml}$ of $20 \mathrm{mmol} / \mathrm{L}$ phosphate buffer containing $10 \mathrm{mmol} / \mathrm{L}$ EDTA at $\mathrm{pH} 7.8$. Then centrifugation was performed at $3600 \times \mathrm{g}$ for 10 min. The supernatant was preferred as the sample of assay. The sample containing $2450 \mu \mathrm{L}$ mixture $(0.3$ $\mathrm{mmol} / \mathrm{L}$ xanthine, $0.6 \mathrm{mmol} / \mathrm{L}$ EDTA, $150 \mu \mathrm{mol} / \mathrm{L} \mathrm{NBT}$, $0.4 \mathrm{~mol} / \mathrm{L} \mathrm{Na} 2 \mathrm{CO} 3,1 \mathrm{~g} / \mathrm{l}$ bovine serum albumin),
$500 \mu \mathrm{L}$ supernatant and $50 \mu \mathrm{L}$ xanthine oxidase $(167 \mathrm{U} / \mathrm{l})$ was vortexed. Afterwards the incubation was carried out for $10 \mathrm{~min}$. Formazan was formed as the result of the reaction. The measurement of absorbance was made on the formazan in purple color at $560 \mathrm{~nm}$. If there would be more enzymes, then there would be a decrease in $\mathrm{O} 2$ - radical reacting with NBT.

\section{Total glutathione analysis}

The measurement of GSH in the total homogenate was carried out by using the method prepared by Sedlak and Lindsay with few changes [14]. Then the weight of the sample was measured and it was homogenized in $2 \mathrm{~mL}$ of $50 \mathrm{mmol} / \mathrm{L}$ Tris- $\mathrm{HCl}$ buffer with $20 \mathrm{mmol} / \mathrm{L}$ EDTA and $0.2 \mathrm{mmol} / \mathrm{L}$ sucrose at $\mathrm{pH}$ 7.5. The mixture was precipitated with $0.1 \mathrm{~mL}$ of $25 \%$ trichloroacetic acid, Afterwards, the precipitate was centrifuged at $1800 \times \mathrm{g}$ for 40 min at $4{ }^{\circ} \mathrm{C}$. Supernatant was preferred in order to identify the level of GSH. $1500 \mu \mathrm{L}$ of measurement buffer $(200 \mathrm{mmol} / \mathrm{L}$ Tris- $\mathrm{HCl}$ buffer containing $0.2 \mathrm{mmol} / \mathrm{L}$ EDTA at $\mathrm{pH} 7.5), 500 \mu \mathrm{L}$ supernatant, $100 \mu \mathrm{L}$ DTNB (10 $\mathrm{mmol} / \mathrm{L}$ ) and $7900 \mu \mathrm{L}$ methanol have been mixed and then vortexed. The mixture was exposed to incubation for $30 \mathrm{~min}$ in $37^{\circ} \mathrm{C}$. 5.5-Dithiobis (2-nitrobenzoic acid) was used as a chromogen. The color was formed into yellow with sulfhydry groups. The measurement of absorbance has been carried out at $412 \mathrm{~nm}$ by means of a spectrophotometer (Beckman DU 500, USA). Finally, a standardized curve was found by means of decreased glutathione $(0.5-1-2-4-8-16-32 \mu \mathrm{M})$.

\section{Glutathione peroxidase analysis}

GPO activity determined by the method of Lawrence and Burk [15]. After the KH2PO4, EDTA, GSH, B$\mathrm{NADPH}, \mathrm{NaN3}$, and GR addition, mixture was incubated. As soon as $\mathrm{H} 2 \mathrm{O} 2$ was added, and the absorbance was carried out every $15 \mathrm{~s}$ for $5 \mathrm{~min}$, at $340 \mathrm{~nm}$.

\section{Glutathione reductase analysis}

GSHRd activity determined spectrophotometrically by measuring the rate of NADPH oxidation at $340 \mathrm{~nm}$ according to Carlberg and Mannervik method [16]. After the NADPH and GSSG addition, the absorbance measured for $5 \mathrm{~min}$ by 30-min intervals at $340 \mathrm{~nm}$ spectrophotometric methods.

\section{Glutathione S transferase activity}

GST activity was determined by Habig and Jakoby [17]. Briefly, the enzyme's activity was assayed spectrophotometrically at $340 \mathrm{~nm}$ in a $4-\mathrm{ml}$ cuvette containing $0.1 \mathrm{M}$ PBS (pH 6.5), 30 mM GSH, 30 mM 1-chloro-2,6-dinitrobenzene, and tissue homogenate. 


\section{Histopathologic examination}

Liver tissues of rats were fixed in 10\% formalin solution for $24 \mathrm{~h}$. All the tissues processed routinely, then $4 \mu \mathrm{m}$ thick sections obtained from the paraffin blocks and stained with Hematoxylin\&Eosin. All sections were examined under a light microscope (Olympus BX 52, Tokyo, Japan) by two pathologists who is aware of which treatment protocol used.

\section{Statistical analyses}

The results obtained from the experiments are depicted as "mean \pm standard error" $(x \pm S E M)$. Normality of the data was tested with Shapiro-Wilk test. All the parameters showed normal distribution. The significance level of the inter-group difference was identified using oneway ANOVA test. Then, Bonferroni post-hoc test was performed. All statistical analyses were performed using "IBM SPSS Statistics Version 22" program and $p<0.05$ was considered significant.

\section{Results}

Biochemical results

Effect of Liv-52 supplementation and I/R on liver enzymes

As showed in Fig. 1, the AST, ALT and LDH activities used in evaluating the liver functions were increased in $\mathrm{I} / \mathrm{R}$ group compared to healthy group and there was a statistically significant difference $(p<0.001)$ between them. This increase due to I/R was suppressed by Liv- 52 application and the difference between $I / R$ group and Liv-52 group was statistically significant $(p<0.001)$. The difference between the healthy group and the Liv-52 group was not significant $(p>0.05)$ (Table 1).

\section{Effect of Liv-52 supplementation on lipid peroxidation and antioxidant status in liver tissue}

As showed in Fig. 2a, the liver MDA level increased with $\mathrm{I} / \mathrm{R}$ application in comparison to the healthy group $(p<$ $0.001)$. In the group treated with Liv-52, this rise due to $\mathrm{I} / \mathrm{R}$ was suppressed and the level was decreased. The difference between I/R and Liv-52 was significant $(p<$ 0.001). There was no significant difference between HG and Liv-52 group $(p>0.05)$. MPO activity was increased due to $\mathrm{I} / \mathrm{R}$ application in comparison to the HG $(p<$ $0.001)$. In the Liv-52 group, MPO level almost decreased to the level of the HG $(p>0.05)$ and the difference between I/R and Liv-52 was significant $(p<0.001)$ (Fig. $2 b)$. SOD activity decreased with $I / R$ application according to HG $(p<0.001)$. Also the difference between $\mathrm{I} / \mathrm{R}$ and Liv-52 was significant $(p<0.001)$ and Liv-52 suppressed the decrease in SOD activity and elevated SOD activity to nearly activity of the HG (Fig. 2c) (Table 1).

\section{Effect of Liv-52 supplementation on tGSH level and activities of glutathione-dependent enzymes in liver tissue} As shown in Fig. 3a, tGSH level decreased with I/R application compared to the $\mathrm{HG}(p<0.001)$. Liv-52 increased the level of tGSH again. There was a significant difference between I/R group and the Liv-52 group $(p<$ $0.001)$.

GPO activity was $28,67 \pm 0,88 \mathrm{U} / \mathrm{g}$ protein in $\mathrm{HG}$ and $\mathrm{I} / \mathrm{R}$ application caused a decrease $(p<0.001)$. This decline due to $I / R$ was suppressed by the application of Liv-52 and increased again, there was a significant difference $(p<0.001)$ between these two groups (Fig. 3b).

As it can be seen in Fig. 3c, liver GSHRd activity decreased in the I/R group according to the HG $(p<$ 0.001). This value increased by Liv- 52 application, difference between Liv-52 and the HG was not significant $(p>0.05)$, but the difference between I/R group and Liv52 group was significant $(p<0.001)$.

GST activity decreased with I/R application compared to the HG and there was a significant difference between these two groups $(p<0.001)$. GST activity increased with Liv-52 application, and the difference between Liv-52 group and the HG was not significant $(p>0.05)$ but there was a significant difference between I/R and Liv-52 groups $(p<0.001)$ (Fig. 3d) (Table 1).

\section{Histopathological results}

As shown in Fig. 4a, healthy group displayed normal liver parenchyma, portal vein, artery, bile ductus and central vein. Conversely, the liver tissue of the I/R applied group
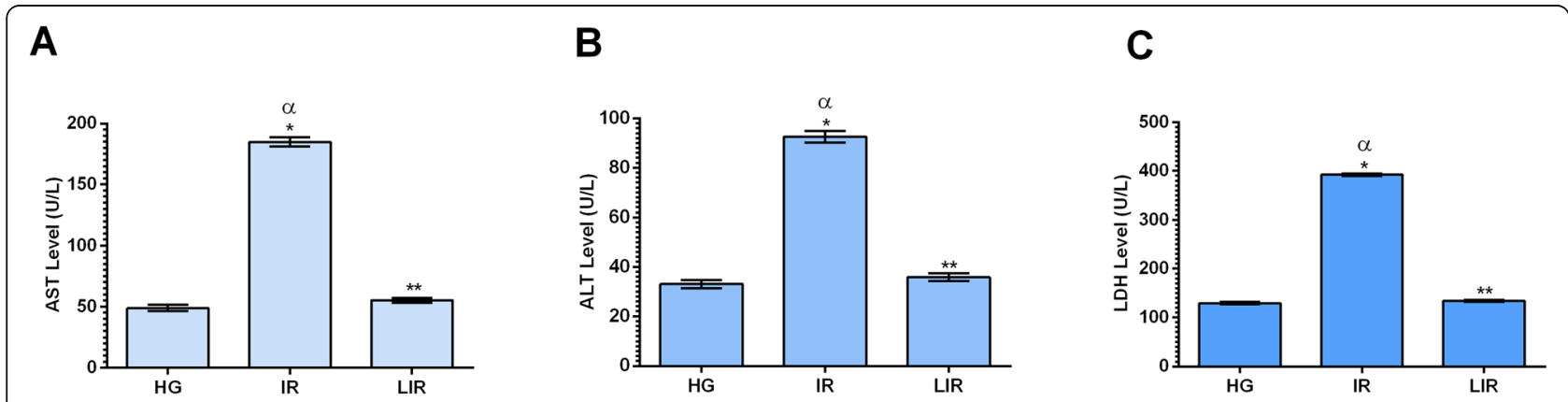

Fig. $1 \mathrm{AST}(\mathbf{a}), \operatorname{ALT}(\mathbf{b}), \mathrm{LDH}(\mathbf{c})$ levels of HG, IR and LIR groups. $(n=6),{ }^{*}=P<0.001,{ }^{* *}=P>0,05$ in comparison to HG group 
Table 1 Biochemical results of the experimental groups

\begin{tabular}{|c|c|c|c|}
\hline & $\begin{array}{l}\text { HG } \\
\text { (Mean } \pm \text { Standard error) }\end{array}$ & $\begin{array}{l}\text { IR } \\
\text { (Mean } \pm \text { Standard error) }\end{array}$ & $\begin{array}{l}\text { LIR } \\
\text { (Mean } \pm \text { Standard error) }\end{array}$ \\
\hline AST (IU/L) & $48.83 \pm 2.63$ & $184.83 \pm 3.72^{\mathrm{a}, \mathrm{b}}$ & $55,17 \pm 2,09^{c}$ \\
\hline ALT (IU/L) & $33.00 \pm 1.73$ & $92.50 \pm 2.36^{a, b}$ & $35.83 \pm 1.54^{c}$ \\
\hline LDH (IU/L) & $129.33 \pm 2.63$ & $392.33 \pm 2.63^{a, b}$ & $133.83 \pm 1.70^{c}$ \\
\hline MDA ( $\mu \mathrm{mol} / \mathrm{g}$ protein) & $1.57 \pm 0.15$ & $4.60 \pm 0.18^{a, b}$ & $1.97 \pm 0.15^{c}$ \\
\hline MPO(U/g protein) & $2.53 \pm 0.17$ & $5.93 \pm 0.22^{a, b}$ & $2.75 \pm 0.22^{c}$ \\
\hline SOD(U/g protein) & $11.33 \pm 0,80$ & $3.35 \pm 0.18^{a, b}$ & $9.13 \pm 0.28^{c}$ \\
\hline tGSH (nmol/g protein) & $25.67 \pm 1.12$ & $3.78 \pm 0.20^{\mathrm{a}, \mathrm{b}}$ & $19.67 \pm 1.12$ \\
\hline GPO(U/g protein) & $28.67 \pm 0.88$ & $4.73 \pm 0.18^{a, b}$ & $23.67 \pm 1.45$ \\
\hline GSHRd(U/g protein) & $17.33 \pm 1.28$ & $5.98 \pm 0.17^{\mathrm{a}, \mathrm{b}}$ & $14.00 \pm 0.97^{c}$ \\
\hline GST(U/g protein) & $21.67 \pm 0.88$ & $7.30 \pm 0.23^{a, b}$ & $18.50 \pm 1.18^{c}$ \\
\hline
\end{tabular}

Abbreviations: HG Healthy group, IR Liver ischemia/ reperfusion, LIR $20 \mathrm{mg} / \mathrm{kg}$ Liv-52+ liver ischemia reperfusion, AST Aspartate aminotransferase, ALT Alanine aminotransferase, $L D H$ Lactate dehydrogenase, MDA Malondialdehyde, MPO Myeloperoxidase, SOD Superoxide dismutase, GSH Total glutathione, GPO Glutathione peroxidase, GSHRd Glutathione reductase, GST Glutathione $\mathrm{S}$ transferase. ${ }^{a}$ means, $p<0.001$ compared to healthy group, ${ }^{\mathrm{b}}$ means $p<0.001$ compared to Liv- $52+\mathrm{IR}$ group, ' means $p>0.05$ compared to healthy group

showed, common hemorrhage, edema, dilated congested blood vessels, dilated congested sinusoids, cells showing balloon degeneration and polymorphic leukocytes (Fig. 4b, c). Near-normal liver tissue was observed in the group treated with Liv-52 except for slight sinusoidal dilation and congestion in the liver tissue (Fig. 4d).

\section{Discussion}

Hemorrhage control procedures performed during surgical operations on blood-rich liver causes $I / R$ damage [18]. Recently, clinical studies carried out in the field of hepatic surgery have focused on how to reduce blood loss and I/R damage more safely [19]. Especially lately, the experimental application of antioxidants on liver $I / R$ damage is also important for understanding the underlying mechanisms. In this study, the effect of the antioxidant features of Liv-52 against liver I/R damage have been examined and the results of the study showed biochemically and histopathologically that Liv-52 exerts a protective effect, preventing oxidative stress and apoptotic tissue damage formed by liver $\mathrm{I} / \mathrm{R}$ damage.

I/R damage leads to the release of enzymes such as ALT which is a specific indicator for cytolysis and hepatic parenchymal damage and AST which is a nonspecific marker [20]. Studies have shown that LDH levels reflecting ALT, AST, and acute liver damages are significantly increased compared to normal group after I/R application [2]. Similarly, I/R significantly increased ALT, AST and LDH levels in our study. It is known that Liv52, a herbal formulation rich in phenolic compounds, significantly reduces infections caused by biological agents and liver damage formed after chemical toxins in humans and experimental animals [21, 22]. There are studies in literature, recommending Liv-52 for liver protection against various hepatotoxins, per 2 or 3 times a day [23]. Also, Liv-52 has been reported to reduce liver enzymes to levels close to the control group in liver damage that is formed by isoniazide and rifampicin [9]. Similarly, increase in liver enzymes due to $I / R$ damage

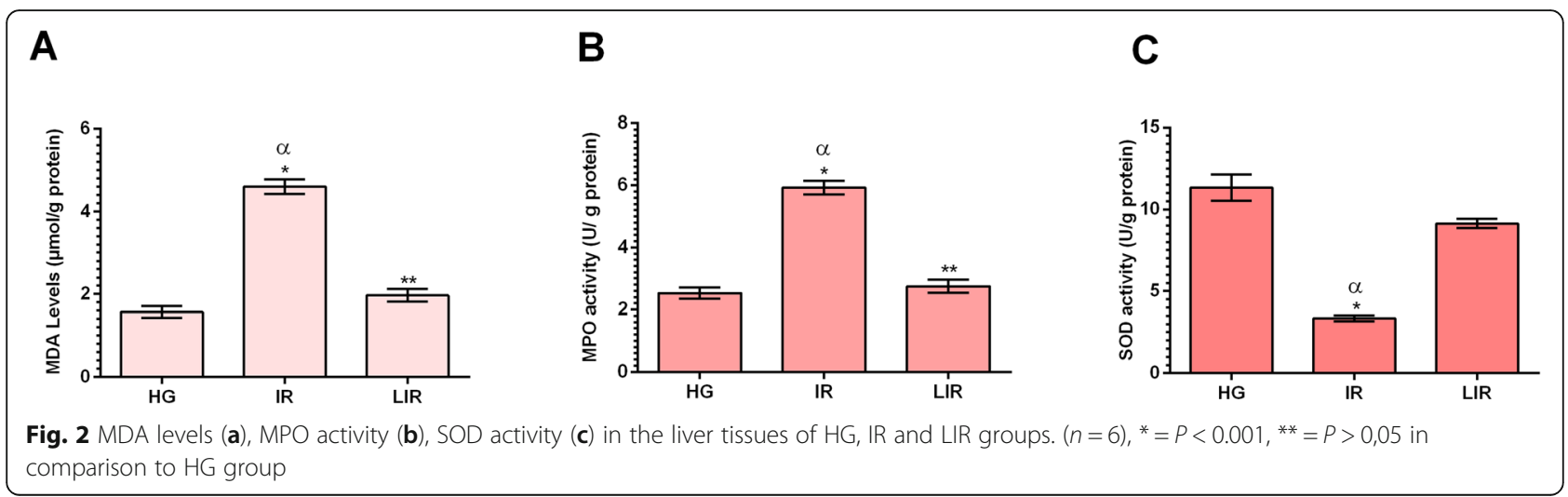




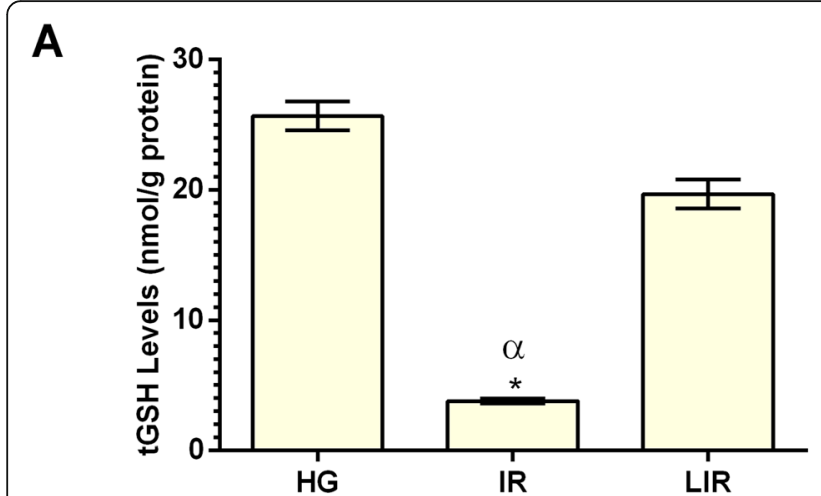

B

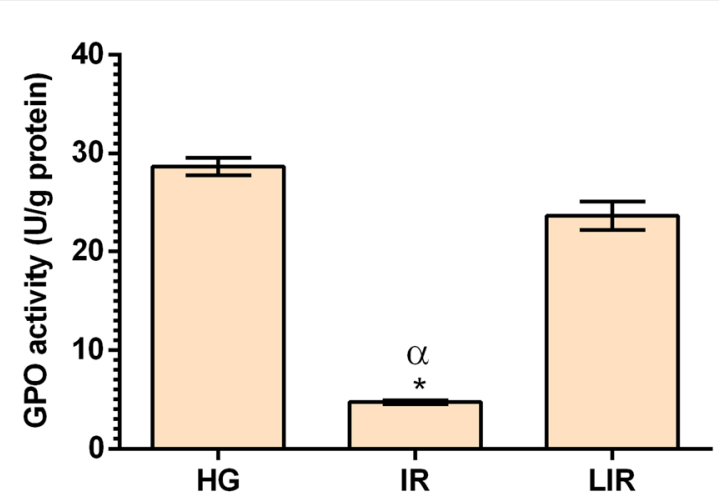

C

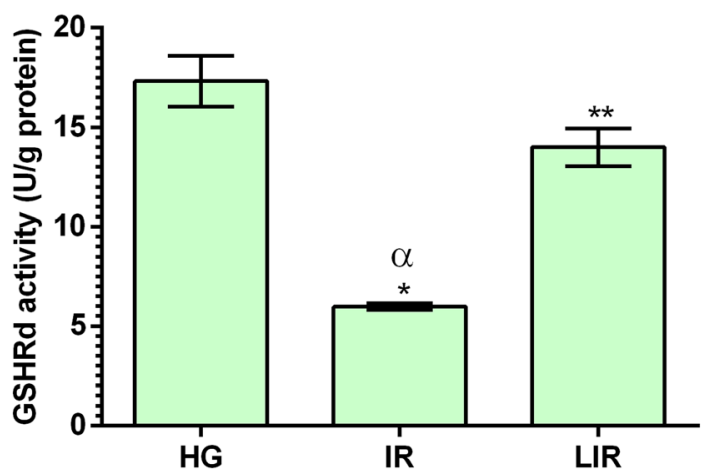

D

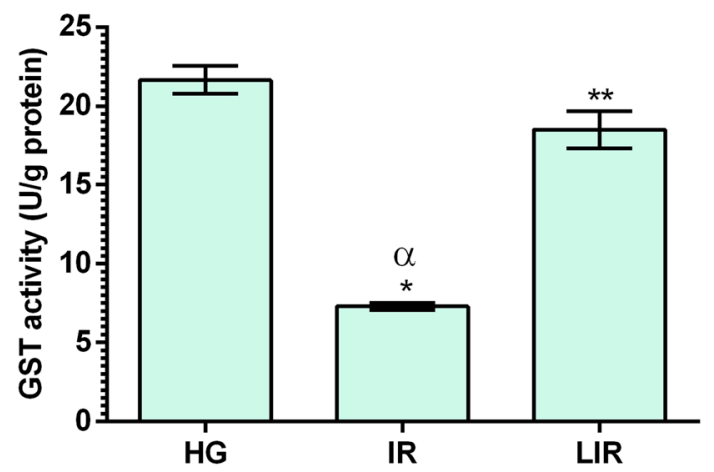

Fig. 3 tGSH (a) level and activities of glutathione-dependent enzymes GPO (b), GSHRd (c), GST (d) in liver tissues of HG, IR and LIR groups. ( $n=6$ ), ${ }^{*}=P<0.001,{ }^{* *}=P>0,05$ in comparison to $\mathrm{HG}$ group

decreased to the level of the healthy group with the application of Liv-52 in our study.

It is also known that Liv-52 suppressed the increased levels of MDA, which is a marker of lipid peroxidation, and SOD, which clears intracellular free radicals, in tertbutyl hydroperoxide induced hepatotoxicity [22]. It has been suggested that liver ischemia affects mitochondrial energy synthesis and electron transport in the respiratory chain as a cause of hypoxia [24], thus produces a large number of free oxygen radicals that triggering cell damage through lipid peroxidation in biological membranes [25].

The studies carried out have shown that I/R application increases oxidative stress parameters such as MDA as well as MPO in the liver and decreases SOD activity [26, 27]. In our study, I/R application increased MDA and MPO levels and decreased SOD activity in accordance with the previous data. The Liv-52 application reversed this condition and showed hepatoprotective effect. There has been no study showing the effect of Liv-52 on MPO in the literature. Our study has indicated that Liv-52 alleviates the inflammatory reaction in the damaged liver tissue which I/R-induced by reducing the hepatic MPO activity.
As known, GSH being an effective antioxidant that protects cells from the damage of the free radicals formed by $I / R$ is present at high concentrations in hepatocytes [28]. Deng et al. reported that the GSH value of the $I / R$ group significantly decreased compared to the normal group and that the GSH value of the I/R + melatonin applied group significantly increased compared to the I/R group after reperfusion, at the 2nd, 4th and 8th hours [2]. In a toxicity study, it has been revealed that $\mathrm{Cu}^{2+}$ application reduced GSH in HepG2 cells by $86 \%$ and that Liv 52 application significantly increased GSH levels in toxic conditions induced by $\mathrm{Cu}^{2+}$ by $74 \%$. In our study, the significantly decreased level of GSH compared to $I / R$ and healthy groups significantly increased with the application of Liv-52 in accordance with the literature.

Reductions in the activities of GPO, GSHRd and GST being glutathione-associated antioxidant enzymes due to liver I/R damage have been previously reported $[29,30]$. GPO, GSHRd, and GST activities in the I/R damaged liver tissue significantly decreased compared to the healthy group in our study. The Liv-52 application suppressed this decline and brought the value to a level close to level of healthy group. Previous studies showed 


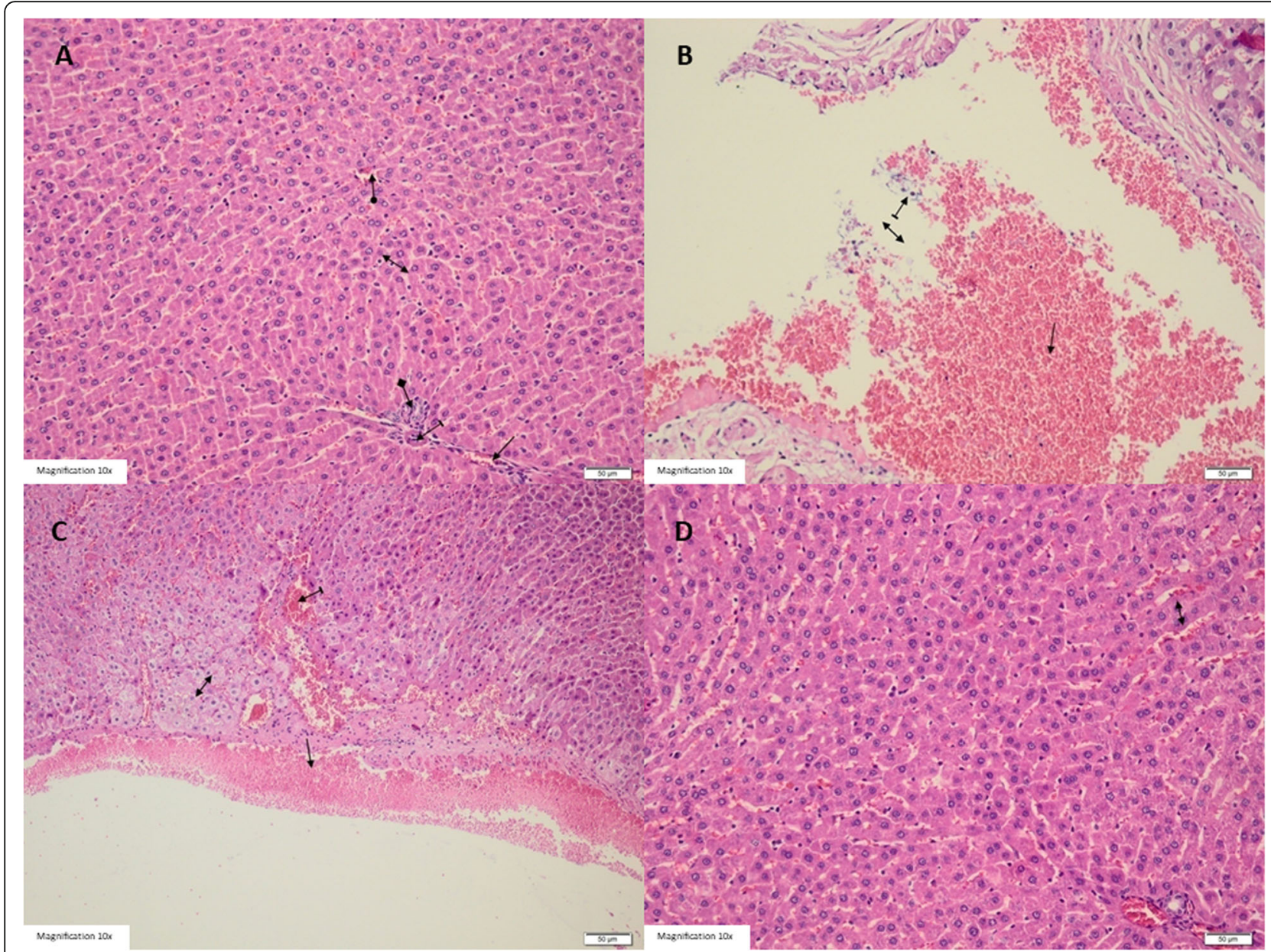

Fig. 4 Histopathological findings of the liver tissues: a Optical microscopic view of HG group: Healthy liver portal vein (straight arrow), artery (dashed arrow), bile ductus (square arrow), central vein (circular arrow), liver parenchyma (two-way arrow). b Optical microscopic view of IR group: Hemorrhage (straight arrow), edema (two-way arrow) and polymorph nuclear leukocytes(dashed arrow) are observed in the ischemia reperfusion applied liver tissue (HEX200). c Optical microscopic view of IR group: Dilated congested blood vessels (straight arrow), dilate congested sinusoids (dashed arrow) and cells showing balloon degeneration (two way arrow) are observed in the ischemic reperfusion applied liver tissue (HEX 200) and (d). Optical microscopic view of LIR group: Near-normal liver tissue is observed in the group treated wofith Liv-52 except for a slight sinusoidal dilation and congestion of the liver tissue (HEX 200)

that Liv-52 significantly increased the levels of serum GPO, reduced glutathione and GST which had been reduced in the paracetamol-induced liver toxicity group in the literature [31]. This information has also supported the results of our study.

The effects of Liv-52 on the liver damage induced by $\mathrm{I} / \mathrm{R}$ were also examined histopathologically in our study. It's shown that $I / R$ application causes degeneration in hepatocyte, vein and intercellular edema and congested sinusoidal damage in the rat liver [32]. It has also been reported that, by the application of Liv-52, hepatocytes become normal histopathologically in the cadmiuminduced hepatic toxicity and Liv-52 reverses cadmiuminduced hepatic damage [33]. In our study, findings such as hemorrhage, edema, dilated congested blood vessels caused by I/R were reduced with the application of Liv52 and near-normal liver tissue was observed. It can be seen with this information that Liv-52, which is known to have hepatoprotective effects previously, also has protective effects on liver $\mathrm{I} / \mathrm{R}$ damage.

\section{Conclusion}

I/R application leads to liver dysfunction and oxidative liver damage. I/R application changed the oxidant antioxidant balance in favor of oxidants. Liv-52 prevented this disequilibrium as well as the I/R-associated hepatic dysfunction. Based on the literature information and our experimental results, we can confirm that Liv- 52 has a therapeutic effect that reduces hepatic damage induced by $I / R$. 


\section{Abbreviations}

ALT: Alanine aminotransferase; AST: Aspartate aminotransferase; GSHR: Glutatione reductase; GSHRd: Glutathione reductase; GST: Glutathione s Transferase; HG: Control group; I/R: Ischemia reperfusion; LDH: Lactate dehydrogenase; LIR: $20 \mathrm{mg} / \mathrm{kg}$ Liv-52 + liver ischemia reperfusion; MDA: Malondialdehyde; MPO: Myeloperoxidase; SOD: Superoxide dismutase; tGSH: Total glutathione

\section{Acknowledgements}

Not applicable.

\section{Authors' contributions}

OC, HE, FKC: conception and design of study, acquisition of data, ABC, NK, AOB: analysis and acquisition of data, revising the manuscript. BS, HS: analysis and interpretation of data, revising the manuscript. RM: conception and design of study, drafting the manuscript, revising the manuscript. KP, EK: revising the manuscript critically for important intellectual content. All authors have participated sufficiently in the work to take responsibility for appropriate portions of the content; and agreed to be accountable for all aspects of the work in ensuring that questions related to the accuracy or integrity of any part of the work are appropriately investigated and resolved have read and approved the manuscript.

\section{Funding}

This research was funded by authors.

\section{Availability of data and materials}

There is no data other than the data given in the article.

\section{Ethics approval and consent to participate}

This experiment was performed in accordance with the National Guidelines for the Use and Care of Laboratory Animals and the study was approved by the Animal Care and Use Committee of Ataturk University, Erzurum, Turkey (Ethics Committee Number: 77040475-000-E.1700216877, Dated:03.08.2017).

\section{Consent for publication}

Not applicable.

\section{Competing interests}

The authors declare that they have no competing interests.

\section{Author details}

'Department of General Surgery, Faculty of Medicine, Erzincan Binali Yildirim University, 24100 Erzincan, Turkey. ${ }^{2}$ Department of Pathology, Faculty of Medicine, Erzincan Binali Yildirim University, 24100 Erzincan, Turkey. ${ }^{3}$ Department of General Surgery, Faculty of Medicine, Karadeniz Technical University, 61000 Trabzon, Turkey. ${ }^{4}$ Department of Biochemistry, Faculty of Medicine, Erzincan Binali Yildirim University, 24100 Erzincan, Turkey.

${ }^{5}$ Department of Pharmacology, Faculty of Medicine, Erzincan Binali Yildirim University, 24100 Erzincan, Turkey.

\section{Received: 26 August 2019 Accepted: 24 December 2019} Published online: 03 January 2020

\section{References}

1. Teoh NC, Farrell GC. Hepatic ischemia reperfusion injury: pathogenic mechanisms and basis for hepatoprotection. J Gastroenterol Hepatol. 2003; 18(8):891-902

2. Deng WS, Xu Q, Liu YE, Jiang CH, Zhou H, Gu L. Effects of melatonin on liver function and lipid peroxidation in a rat model of hepatic ischemia/ reperfusion injury. Exp Ther Med. 2016;11(5):1955-60.

3. Collard CD, Gelman S. Pathophysiology, clinical manifestations, and prevention of ischemia-reperfusion injury. Anesthesiology. 2001;94(6):11338.

4. Marnett LJ. Oxyradicals and DNA damage. Carcinogenesis. 2000;21(3):36170.

5. Demiryilmaz I, Turan MI, Kisaoglu A, Gulapoglu M, Yilmaz I, Suleyman H. Protective effect of nimesulide against hepatic ischemia/reperfusion injury in rats: effects on oxidant/antioxidants, DNA mutation and COX-1/COX-2 levels. Pharmacol Rep. 2014;66(4):647-52.
6. Vidyashankar S, Sharath Kumar LM, Barooah V, Sandeep Varma R, Nandakumar KS, Patki PS. Liv.52 up-regulates cellular antioxidants and increase glucose uptake to circumvent oleic acid induced hepatic steatosis in HepG2 cells. Phytomedicine. 2012;19(13):1156-65.

7. Sandhir R, Gill KD. Hepatoprotective effects of Liv-52 on ethanol induced liver damage in rats. Indian J Exp Biol. 1999;37(8):762-6 PMID: 10709323.

8. Kuyrukluyildiz U, Binici O, Cetin N, Balci MG, Onk D, Cankaya M, Kafa A, Taskin H, Altuner D, Yilmaz A. Liv-52; prophylactic or therapeutic agent against Desflurane-induced hepatotoxicity in rats. Lat Am J Pharm. 2016;35: 1169-76.

9. Sankar M, Rajkumar J, Sridhar D. Hepatoprotective activity of heptoplus on isoniazid and rifampicin induced liver damage in rats. Indian J Pharm Sci. 2015;77(5):556.

10. Bradford MM. A rapid and sensitive method for the quantitation of microgram quantities of protein utilizing the principle of protein-dye binding. Anal Biochem. 1976;72(1-2):248-54.

11. Ohkawa H, Ohishi N, Yagi K. Assay for lipid peroxides in animal tissues by thiobarbituric acid reaction. Anal Biochem. 1979;95(2):351-8.

12. Wei $H$, Frenkel $K$. In vivo formation of oxidized DNA bases in tumor promoter-treated mouse skin. Cancer Res. 1991;51(16):4443-9. 1868465.

13. Sun Y, Oberley LW, Li Y. A simple method for clinical assay of superoxide dismutase. Clin Chem. 1988;34(3):497-500. 3349599.

14. Sedlak J, Lindsay RH. Estimation of total, protein-bound, and nonprotein sulfhydryl groups in tissue with Ellman's reagent. Anal Biochem. 1968;25(1): 192-205.

15. Lawrence RA, Burk RF. Glutathione peroxidase activity in selenium-deficient rat liver. Biochem Biophys Res Commun. 1976:425(3):503-9.

16. Carlberg I, Mannervik B. Glutathione reductase. Methods Enzymol. 1985;113: 484-90.

17. Habig WH, Jakoby WB. Assays for differentiation of glutathione Stransferases. Methods Enzymol. 1981;77:398-405.

18. Jin LM, Jin SF, Liu YX, Zhou L, Xie HY, Yan S, Xu X, Zheng SS. Ischemic preconditioning enhances hepatocyte proliferation in the early phase after ischemia under hemi-hepatectomy in rats. Hepatobiliary Pancreat Dis Int. 2012;11(5):521-6.

19. Perez JC, Ramirez AC, Gonzalez LT, Espinosa LE, Quintana MM, Galvan GA, Chavira HZ, de la Garza FJ, Lemarroy CR, Garza NE, et al. Spironolactone effect in hepatic ischemia/reperfusion injury in Wistar rats. Oxidative Med Cell Longev. 2016;2016:3196431 PMID: 26798418.

20. Gedik E, Girgin S, Obay BD, Ozturk H, Ozturk H, Buyukbayram H. Iloprost, a prostacyclin (PGI2) analogue, reduces liver injury in hepatic ischemiareperfusion in rats. Acta Cir Bras. 2009;24(3):226-32.

21. Vidyashankar S, Patki PS. Liv.52 attenuate copper induced toxicity by inhibiting glutathione depletion and increased antioxidant enzyme activity in HepG2 cells. Food Chem Toxicol. 2010;48(7):1863-8.

22. Vidyashankar S. S KM, Nandakumar KS: liv.52 protects HepG2 cells from oxidative damage induced by tert-butyl hydroperoxide. Mol Cell Biochem. 2010;333(1-2):41-8.

23. Nimesh S. Shubham. Pharmacological strategies on medicinal plants as Hepatoprotective agents. Acta Sci Pharm Sci. 2019;3:09-14.

24. Peralta C, Jimenez-Castro MB, Gracia-Sancho J. Hepatic ischemia and reperfusion injury: effects on the liver sinusoidal milieu. J Hepatol. 2013; 59(5):1094-106.

25. Jaeschke H, Woolbright BL. Current strategies to minimize hepatic ischemiareperfusion injury by targeting reactive oxygen species. Transplant Rev (Orlando). 2012;26(2):103-14.

26. Abd-Elbaset M, Arafa EA, El Sherbiny GA, Abdel-Bakky MS, Elgendy AN. Thymoquinone mitigate ischemia-reperfusion-induced liver injury in rats: a pivotal role of nitric oxide signaling pathway. Naunyn Schmiedeberg's Arch Pharmacol. 2017:390(1):69-76.

27. Mard SA, Akbari G, Dianat M, Mansouri E. The effect of zinc sulfate on miR122, miR-34a, Atioxidants, biochemical and Histopathological parameters following hepatic ischemia/reperfusion injury in rats. Biol Trace Elem Res. 2019;188(2):434-40.

28. Yuan L, Kaplowitz N. Glutathione in liver diseases and hepatotoxicity. Mol Asp Med. 2009;30(1-2):29-41.

29. Zaki AM, El-Tanbouly DM, Abdelsalam RM, Zaki HF. Plumbagin ameliorates hepatic ischemia-reperfusion injury in rats: role of high mobility group box 1 in inflammation, oxidative stress and apoptosis. Biomed Pharmacother. 2018;106:785-93. 
30. Kunak CS, Kukula O, Mutlu E, Genc F, Peker GG, Kuyrukluyildiz U, Binici O, Altuner $\mathrm{D}$, Alp $\mathrm{HH}$. The effect of Etoricoxib on hepatic ischemia-reperfusion injury in rats. Oxidative Med Cell Longev. 2015;2015:598162.

31. Iroanya OO, Adebesin OA, Okpuzor J. Evaluation of the Hepato and Nephron-Protective Effect of a Polyherbal Mixture using Wistar Albino Rats. J Clin Diagn Res. 2014;8(6):Hc15-21.

32. Uylas MU, Sahin A, Sahinturk V, Alatas IO. Quercetin dose affects the fate of hepatic ischemia and reperfusion injury in rats: an experimental research. Int J Surg. 2018;53:117-21.

33. Jeyaprakash $\mathrm{K}$, Chinnaswamy P. Effect of spirulina and Liv-52 on cadmium induced toxicity in albino rats. Indian J Exp Biol. 2005;43(9):773-81 PMID: 16187527.

\section{Publisher's Note}

Springer Nature remains neutral with regard to jurisdictional claims in published maps and institutional affiliations.

Ready to submit your research? Choose BMC and benefit from:

- fast, convenient online submission

- thorough peer review by experienced researchers in your field

- rapid publication on acceptance

- support for research data, including large and complex data types

- gold Open Access which fosters wider collaboration and increased citations

- maximum visibility for your research: over $100 \mathrm{M}$ website views per year

At BMC, research is always in progress.

Learn more biomedcentral.com/submissions 